\title{
Federation without affirmation: A sketch of a revisionist program of research into '1901'
}

\author{
William Coleman ${ }^{1}$
}

\section{Abstract}

The Federation in 1901 of six colonies into a Commonwealth of Australia is the most researched episode in Australian political history. But for all its bulk and sophistication, this research remains underdeveloped. The root of the trouble is the 'affirmative' premise of almost every page of this history regarding its subject matter, Federation. This article identifies some unexcavated sites in the intensely worked field of Federation history that may supply useful matter for a revisionist history.

\section{Introduction}

The Federation in 1901 of six colonies into a Commonwealth of Australia is surely the most researched episode in Australian political history. But for all its bulk and sophistication, this research remains underdeveloped-misshapen, even. The root of the trouble is the 'affirmative' premise of this history regarding its subject matter, Federation. To illustrate: the relevant entry in the Oxford Companion to Australian History describes Federation as an 'achievement', 'the greatest political achievement in Australian history' (Davison et al., 2001, p. 245). Achievement is a approbative

\footnotetext{
1 College of Business and Economics, The Australian National University. William.coleman@anu.edu.au. The author is indebted to a referee on several points. The article's arguments are more extensively developed in Their Fiery Cross of Union: A Revisionist Retelling of the Creation of the Australian Commonwealth, 1889-1914, Australian Scholarly Publishing (forthcoming).
} 
term. One well-known dictionary offers as a definition, 'a great or heroic deed'. Such a characterisation of Federation, in different degrees of intensity, is an implicit premise of just about every page ever written of Federation history. ${ }^{2}$

A handful of celebratory and 'memorialising' chronicles, composed between 1900 and 1950, constitute the foundation of the received history of Australian Federation. In those years of living memory, the most literary of the Federationists-Alfred Deakin, B.R. Wise, John Quick and Robert Garran ${ }^{3}$ - took up the pen to fashion what they hoped would endure as the authorised account of these events. Theirs was a triumphalist story of the valiant struggling against villains, clods and a clown or two. The second phase of Federation history-that crafted by the professional historical investigators of the first generation after the Second World War-did see some greys appear on the palette. But none of this retouching by postwar historians altered an essentially positive outlook of Federation. The third period-say about the time of the Bicentenary until the present—saw a mottling of attitudes. External events deflated enthusiasts. The policy regimen, which was inseparably associated with Federation - tagged as the 'Australian settlement', but in fact the 'Federation settlement' - was after eight decades disowned in the post-1988 period. Perhaps independentlybut to the same effect, the momentum of professional history continued to grind away at the mythology. But for all the seeming distancing, any frank slight of Federation remains rare. If, to the left, Federation is no longer magnificent, it is still beneficent. And to the right, it is something that only an unpatriotic knocker would want to take down The centenary of Federation underlined the endurance of the essential consensus. It occasioned a flood of Commonwealth-funded scholarly studies that were perfectly content with an 'affirmative' interpretation of the history of Federation. ${ }^{4}$ A plaster cast nobility of '1901', then, remains tolerated, respected and even added to by the past generation. Thus, notwithstanding some well-aimed

\footnotetext{
2 Crisp (1990), Botsman (2000) and Grimshaw (2002) may seem exceptions. But Crisp's dissatisfaction with Federation is merely that it did not go far enough; it did not produce unification. Botsman's objection is not to the creation of the Commonwealth, but to its conservation of the imperial tie. The brilliant essays of Martin (2001 and 2003) are perhaps the closest in the literature to a revisionist outlook.

3 Deakin (1944), Wise (1913), Quick and Garran (1901), and Garran (1936). Hall (1931) also needs mention, as the one piece of 'research history' of the phase. The earliest instance of the received version to appear in print, apart from Quick and Garran, is the potted history of the Federation movement supplied by Bryce in his Constitutions of 1905, which wholly breathes the presumptions of Deakin etc. Perhaps the final chapter of this phase of Federation history is 'The First Five Prime Ministers of Australia' by Robert Broinowski (1949), one of the troop of bright young right-hand men of the Federationist cause. In hypothesising that Edmund Barton was named 'Edmund' in honour of 'Sir Edmund Parry', the paper illustrates the 'inspirational' and not very probing flavour of this phase of history. Given that the hero of the Arctic had judged Barton's father as 'insolent and insubordinate' in their brief and bitter encounter, it is unlikely Edmund was named in his honour. And 'Sir Edmund' was, in fact, 'Sir Edward'. 4 Not only scholars benefited: 'Both the Liberal Party and the ALP received grants from the Council for Centenary of Federation projects to mark their respective contributions to Australia's development during its first century as a nation' (Nethercote, 2002, p. 13).
} 
stings, John Hirst's The Sentimental Nation - the most significant and balanced single account of 1901 - does not baulk at its own sentimental gesture: the work is dedicated to 'the 422,778 Yes voters who have no other memorial'.

Even the best history, then, remains, at bottom, an act of giving thanks for Federation. And in popular, textbook and 'official' history, the myth-making of the first generation remains pervasive. Thus kept in general circulation is a ritualistic, commemorative, even legendary history of Australia's Federation episode.

So for the questioner who asks 'how can anything new can be found in the field Federation, so exhaustively prospected, mined, sieved and sifted?', there is an answer. What about an account of Federation that is not, at bottom, an exercise in giving thanks for it? There is a new thought.

The papers of this Agenda symposium are a gesture towards such an account.

The present paper identifies some unexcavated sites in the intensely worked field of Federation, which may well serve a revisionist history.

\section{Some deconstruction}

Perhaps the place to embark on a revisionist treatment of history is at the fonts of orthodoxy, and puncture the prestige of some of its texts.

The first is Deakin's The Federal Story (or 'Federal Fable' or 'Federal Fantasy'), first published in 1944. The author was a talented and experienced journalist, and in Federal Story he wrote a long editorial in honour of his cause, and philippic against certain miscreants, Lyne and Reid. ${ }^{6}$ But, beyond its initial publication, it has been republished twice. This honour is doubtless in part because its literary charm is so great, almost irresistible. But I suspect this honour is traceable to the fact-as with the faithful to sacred scripture - the actual truth or falsehood is not the point; it is inspiring, uplifting, true 'in spirit', and that is enough. Granted: to criticise Federal Story, seems a bit like fact-checking a poem. But its mythologisations are taken as matter of fact, ${ }^{7}$ and it would be a worthy task for this piece of scripture to receive its own taste of biblical criticism.

\footnotetext{
5 Mark also Hirst's rather lame exoneration of the Immigration Restriction Act 1901: 'It is common now to denounce the White Australia policy as racist and nothing more. It is certainly racist, but it also embodied the hopes for Australia as a better world' (Hirst, 2000, p. 22). I guess many terrible deeds—deeds immensely more evil than the Immigration Restriction Act-have embodied the hopes of their authors for a better world.

6 Deakin claimed Reid 'never read a book unless it was a sensation novel', the ultimate damnation, presumably. James R. Tyrell records Reid as a 'reader' and 'regular patron' of the Sydney Book Club (Tyrell, 1987, p. 67). Deakin's sulphurous judgement contrasts strangely with the gallant treatment he affords Reid in his anonymous Morning Chronicle columns (Deakin, 1968).

7 For example, Deakin's account of the controversy of May 1900 over appeals to the Privy Council.
} 
A different task awaits for whoever embarks of the massive task of deconstructing Quick and Garran's 1901 The Annotated Constitution of the Australian Commonwealth. This is a tendentious account of Federation and the Constitution, but for all that it was treated as 'the Bible' by constitutional lawyers for many years, and was reissued in 1995, 2002 and 2015. It would be a worthy, if arduous, accomplishment to patiently expose the tenacious partisanship of its 1,008 crammed pages. ${ }^{8}$ Perhaps more dialectical guile would be called for in laying bare Wise's The Making of the Australian Commonwealth (1913). Rightly distrusted by both his allies and opponents, why should we trust it?

\section{Myth-busting}

Perhaps the core revisionist remedy is the negative task of demolishing myths.

\section{'The distinguished gentlemen'}

One of the vulnerable structures is the overinflated and always gilded representations of the Federation Fathers.

Alfred Deakin's life has been intensely researched. The composite picture is revelatory, sometimes unnerving, but always fundamentally admiring. Very few have confronted that, for all Deakin's brilliance and charm, there was something inhuman about him, possessed, as he was, by an all-excluding passion for personal mastery over events and persons.

By contrast to Deakin, George Reid was left by received history in no need of deflation. On the contrary, he needed rescue from the literary bile of Deakin and Wise. And he received it: beginning with Evatt (1945), and followed by Crisp (1990), and Nairn (1973). Reid's sole and meticulous biographer concurred with the tendency of their conclusions (McMinn, 1989). To all these historians, Reid made Federation possible, and that is true enough. But he was also 'a great Australian' (Nairn, 1973, p. 47). This is the question: was Reid a great man, or one faithless to persons and principles? A cloaked, clever, ambitious temporiser? The case against Reid is far from exhausted by the venting by Deakin and Wise of their personal resentments.

It is with Edward Barton that the gap between reality and representation is the greatest. The most accomplished general history of Federation describes Barton 'calm, devoted, high minded' with 'no indication he wanted glory for himself' (Hirst, 2000, p. 132). A thumbnail refutation of these remarkable affirmations is not possible. The present writer can here only submit that in such words he has

8 A compare-and-contrast with Moore's The Constitution of the Commonwealth of Australia (1902) would be a worthy exercise. 
zero sense of recognition of the flesh and blood Edmund Barton. More importantly, the present writer would venture that all biographical inquirers into Barton the man have sensed his frailties (see the introductions of Reynolds (1948) and Bolton (2000)). Such inquiries have exposed some of Barton's weaknesses. But for all that, there is in these biographies a holding back, an exercise of a courteous leniency, in considering Barton. It remains to be acknowledged that Barton was acutely flawed in character, without a noteworthy gift for anything beyond a certain talent for evanescent popularity. Many politicians, it may returned, can be judged the same. But can such a politician be Australia's 'noblest son'?

Barton's only constituency is the celebrants of Federation. Charles Kingston, by contrast, has his own very definite constituency-beginning with The Bulletin, and enduring long into the twentieth century—as a 'radical', 'democrat' and 'nationalist' hero. The 'radical' characterisation needs to confront his relatively moderate positioning in the convention. The democrat characterisation needs to ponder his wish to entrench the entire federal constitution by requiring any revision to obtain the approval of at least two-thirds of voters at a referendum. The 'nationalist' descriptor is anachronistic, and needs reconciliation with Kingston's public affirmation, on the eve of Federation, that Australia 'was prepared to spend its last penny and last man in maintaining' the British Empire (Daily Telegraph, 30 May 1900). Those warmed by his supposed nationalism might ask to what degree it was part and parcel of his brutal vehemence against Chinese immigration? The veneration needs to confront the plain fact that Kingston was a 'terrible bully' to his inferiors (Tennyson, 1978, p. 294), a psychological blight that culminated in his tyrannical administration of the inaugural Customs Tariff Act 1902. The Kingston myth is in need of some truth serum, but has furnished 120 years of adulation, forbearance and a certain averting of eyes from the obvious. The last is especially seen in the fact that no one seems to have registered the overwhelming probability that Kingston's total mental (and physical) collapse in his 50s was a matter of neurosyphilis.

The recovery of 'the historical Kingston' might not only serve truth-telling, it might fill out the story of Federation. In received history, Kingston seems without an important role; Clark was the ideologist, Griffith was the legal counsel, Deakin the strategist, Barton the front man—and Reid the foil. And Kingston? He allegedly drafted the Enabling Acts for the convention in a single night; a feat of virtuosity rather than importance. His leading credit is commonly a very early draft of what ultimately became the Constitution Act of Australia. But the emergence in the last 30 years of Inglis Clark's significance has dimmed that claim. And the drafts were very much a cut-and-paste from existing statutes and constitutions. Perhaps the truth is Kingston lacked an important role-perhaps Kingston is only memorable being various things (a 'radical' etc.), rather than doing various things. A fresh look at Kingston finds a man who, in his prime, had a flexibility in dealing with 
majorities, which his browbeating of individuals belies. ${ }^{9}$ A fresh look might also find some significance in his unexpected personal friendships with the (presumably 'un-radical') free-trader Federationists, Symon and Glynn and Reid, the last of whom 'liked him immensely'.

\section{Popularity}

Part of the myth of the first phase of received history is great popularity of the Federationist cause, at least at its apogee-apparently evinced by a majority voting 'Yes' in each of 10 referendums between 1898 and 1900.

But it has long been acknowledged (Crisp, 1949) that, by all reasonable benchmarks, the turnout at the Federation referendums was weak. In only one of those 10 referendums did a majority of those eligible to vote cast a vote for 'Yes'. ${ }^{10}$ And, with respect to the notion of a 'popular' mandate more generally, in none of these referendums did the 'Yes' vote amount to anything near a majority of adults, not even in Western Australia (WA).

But another criticism of the democratic mandate has not been dealt with. Behind those totals of 'Yes' and 'No' savoured by Quick and Garran lies an extreme variation, which comprehended great chunks of 'No'. Thus a majority of Sydney voted 'No' both in 1898 and 1899. Australia's most populous city (narrowly), its largest port (easily), the creative centre of its literary life, the capital of its most economically significant state voted 'No', if only just. ${ }^{11}$ The received history is close-mouthed on this. It is implicitly recognised in the maps of Parker (1949), and mentioned in single sentences by Bolton (2000, p. 198), Crisp (1990, p. 341), and Hirst (2000, p. 199). In the mountains of literature on Federation, where else? Gorman's investigation of 'Why Sydney voted no' (this issue) is the first paper to give more than fleeting notice to this discomfiting fact. ${ }^{12}$

\footnotetext{
9 Kingston put it this way: he recognised only one master: 'the majority of the Assembly' (Morning, 19 September 1900).

10 Reported Yes ballots in WA constituted 50.004(!) per cent of the reported roll. But the abundance of fraudulent enrolments in this referendum leaves this microscopic majority fictitious.

11 The exact margin will depend on how 'Sydney' is defined. Using the definition of the 'Greater Sydney Region' (Palm Beach-La Perouse-Liverpool-Dural) provided in Clifford et al. (2006), No received 50.3 per cent of the votes validly cast, or 34,667 of 68,968.

12 Federationists, logically enough, considered this fact only discomfiting to Sydney: thus the scolding Sydney sometimes received in the early Commonwealth parliaments for its shameful disloyalty. Brisbane also voted No, but this has received distinct attention. The first page of the first chapter of a history of twentieth-century Queensland squarely notes it (Fitzgerald, 2002).
} 


\section{Motivation}

Federation was, after all, meant to secure federation, not unification. But how many were actually moved to create a federal structure? One might be tempted to judge their intentions by the fruits of what they wrought.

By the twenty-first century there can be few federal nations as centralised as Australia. Even in the United Kingdom, Scotland and Northern Ireland have greater independent power than Australian states. (Pomfret, this issue)

Tempting, but not respectful of unintended consequences. Nevertheless, it is hard to detect any genuine federal spirit in the power-mongering of Deakin, the glorychasing of Parkes or the office-seeking of Barton. You will find frank avowals of unificationism at the Australasian Federal Convention by William Lyne and B.R. Wise. And outside the convention, you will find some nationalism, but as Melleuish (this issue) stresses, nationalism is acutely hostile to federalism. It is true there were delegates to the convention who stuck out for a federal structure, especially South Australians. But it would be worthwhile to inquire how much federal spirit can be found once they threw their personal lot in after 1901. And Griffith. The oft-repeated claim is that the pre-1920 High Court of Griffith was profoundly less centralist than its successor. But that is a relative claim. How much spirit of federalism there was in the Griffith court is thrown into doubt in some of its own judgments, such as its remarkable decision that federal politicians were exempt from state income tax. ${ }^{13}$ (Were state politicians to be exempt from customs duties? ${ }^{14}$ ) Historians would do well to review the supposed federalism of the Griffith court, not by the standards of Higgins and Isaacs, but, say, by the discernible expectations of Clark and Moore.

Obviously, there are worthy motivations that are neither federal nor unificationist. Thus Phelps (this issue) strongly argues that, contrary to common presumption, defence was a key motivator. One may retort that if defence was 'subjectively' important in the late 1890s, it was not, surely, 'objectively' important; and to the extent it was not objectively important, the real motivator of Federationists would be better described as some irrational anxiety about defence. But in distinguishing 'subjective' from 'objective', we have moved from motivations to functions.

\section{Functionality}

Myth-busting can extend to the proposed justifications for Federation.

13 Deakin v Webb (1904) HCA 57; 1 CLR 585 (3 November 1904).

14 Under Joseph Carruthers, the NSW Government unsuccessfully appealed to the High Court to be exempt from customs (Attorney-General (NSW) v Collector of Customs (NSW) (1904) HCA 28; 5 CLR 818 (23 May 1908)). But Carruthers never claimed that his own purchases of wire netting should be exempt. 
One of these is the existence of interstate tariffs prior to Federation. The vexation and scandal of these barriers to intra-Australian trade was, and is, a staple of Federationist rhetoric. And more, there lay a glorious promise in their removal. Thus Andrew Garran, later to be Reid's man in the Legislative Council, declared 'The gain if we establish inter-colonial free trade will be enormous. Australia as a whole will enter a fresh epoch' (New South Wales Parliamentary Debates, 5 June 1890). One may well be sceptical of the epochal implications of their removal. Recall that in the wake of Reid's Customs Act 1895, the rest of Australia could by 1 July 1900 export any good to New South Wales (NSW) perfectly free of tariff, apart from alcohol, tobacco products, tea and opium. ${ }^{15}$ And as Lloyd (2015) has revealed, the tariffs of the remaining colonies on imports from Australia were slight. Finally, there is a theoretical naivety in the joy of free traders such as Andrew Garran at the prospect of Victoria, South Australia (SA) etc. removing their tariffs on one another. For while the well-known the arguments of the economist, rooted in David Ricardo and W. Stanley Jevons, easily rationalise the proposition that the abolition of tariffs will benefit an economy considered as whole, the very same pattern of argument will conclude that an economy may be harmed by abolishing a tariff on imports from one source but not from all sources (Viner, 2013 [1950] is the classic reference). To illustrate: while SA will certainly benefit from reducing tariffs on hops, whatever their source, SA may be harmed by reducing its tariff on Victoria's hops alone, while maintaining tariffs on hops imports from the rest of the world. ${ }^{16}$ A special case brings out this perhaps recondite-seeming proposition: if Victoria's hops supply is insufficient to satisfy all of SA's hops demand, then SA must be harmed by such a tariff concession to Victoria only. For such a concession will not reduce the price of hops in SA, since the price of the still-required imports from the rest of the world still reflect the tariff. And since the price is unreduced, the concession neither benefits the SA consumer nor harms the SA producer. But the concession certainly will reduce SA's tariff revenue. And it will, certainly, increase Victorian hops producers' incomes, as they now sell in SA at the high price resulting from the tariff. In effect, $S A$ tariff revenue (say $£ 1,000$ ?) has been spent on offering a subsidy for any Victorian hops exported to SA; an unenticing policy to SA, certainly. And, crucially, Victoria cannot, without harming itself, provide sweeteners in return sufficient for SA to agree to such a concession. For the (de facto) subsidy to the production of Victorian hops, of, say, $£ 1,000$, cannot have increased the income to Victorian hops producers by $£ 1,000 .{ }^{17}$ The upshot is that the increase in incomes of Victorian hop producers is less than the reduction in SA tariff revenue; or, in other words, the gain to Victoria is less than the loss to SA. Thus Victoria cannot

15 An amending Act in December 1898 cancelled for sugar and sugar products the final reduction scheduled by the Act of 1895.

16 A celebrated proposition in the economics of international trade: see Jacob Viner (2013 [1950]).

17 The subsidy, say $£ 1,000$, increases production by a certain amount, but that amount must be produced at some loss, disregarding the subsidy — otherwise it would have been produced without the subsidy. Thus the net gain of Victorian hop producers is the $£ 1,000$ less that loss. 
compensate SA sufficient for it to agree to such a concession, and still be better off itself; and so the two communities, considered in the aggregate, are worse off. ${ }^{18}$ The lesson of this example lessens surprise at the failure of attempts to secure intraAustralian free trade deals—such as that proposed between SA and New Zealand. It is possible that the terms of the mooted agreement were such that if SA was ahead, then New Zealand must be behind, with no possibility of SA being able to compensate $\ldots$ or vice versa. ${ }^{19}$

A trickier challenge is to bust myths concerning the supposed 'cultural' grounds for Federation. The chief of these is 'nationalism'. In popular Federationist history, this interpretation amounts the anachronistic projection onto the 1890s of attitudes current in Australia a century later. Formal history of Federation, by contrast, has paid close attention to the intense imperial consciousness of Federationists (Meaney, 2001; Souter, 1976)— their Union Jack waving, their Britannia Rule the Waves singing, and their recurrent use of Tennyson's lines:

One life, one flag, one fleet, one throne!

Britons, hold your own!

The political actors who did not share this consciousness (say, Thomas McIlwraith on 'the right' and republican orators on 'the left') played no role in the Federation movement that gelled from 1895, and actively opposed it. Thus it might be held that Australian Federationists were Imperial Federationists: their fundamental aspiration was to strengthen both the Empire and Australia by establishing Australia as a fully fledged province of a Greater Britain. Did not Parkes, just 10 days after the 'Tenterfield Oration', write to Salisbury to propose 'a great National Council in which all parts of the Empire should be represented on terms of equality' (quoted in Hyam \& Martin, 1975, p. 132)?

And yet it can hardly be said that Australian nationalism was absent or marginal to Federation. The Australian Natives Association, for all its conventional 'loyalty', was noisily nationalist and Federationist. The phrase 'to make a nation' is no anachronism. As a stated motivation for Federation, it seems to have issued from the lips of Federationists with a frequency comparable to the phrase 'to consolidate the Empire'.

Complicating the matter is that nationalist and the imperialist sentiments could be felt simultaneously. Thus, at the time of the impasse in London over limiting appeals to Privy Council- a favourite incident in nationalist constructions of Federationthe following letter appeared in the Evening News (19 April 1900):

18 No matter what commodities might be added in some SA-Victoria 'free trade agreement', the logic is that at least one of two economies is worse off, and possibly both.

19 In 1895, New Zealand and SA were on the verge of agreement that would admit New Zealand hops to SA, and SA wine to New Zealand, free of duty. But while the legislation was passed by New Zealand, it was abandoned in SA, 'the natural result of the belief that it would give much to New Zealand but little to SA' (Pulsford, 1917, p. 144). 
Sir, - I am one who worked in my own little way to make Australia a nation, but I never dreamt that while assisting to federate Australia I was at the same time helping to sever one of the links which bind Australia to the Empire.

Civis

So what to make of this letter writer? There are at least three logical possibilities.

Perhaps antithetical sentiments (nationalism and empire-ism) simply coexisted in the same breast. Is not some incoherence in political professions almost to be expected? ${ }^{20}$

Alternatively, perhaps only one of the two sentiments of Civis is genuine, and the other is fake, inauthentic and put on (perhaps even without realising).

Third, one might try reconcile what is apparently contradictory. To that end, distinctions have been advanced between patriotism and nationalism, and between the love of a locality and allegiance to sovereign. How much do these distinctions help? An alternative frontal attack might note that nation may be a colony; and therefore, there exists at least the logical possibility of aspiring to make a colonial nation. A 'colonial nationalism', indeed. Logically possible, but, to our ideas, weird, and, to our usages, hardly 'nationalist'.

The matter remains perplexing (see Ergas in this issue).

\section{Superiority}

If Federation had a functionality - that is, it constituted a solution-that does not make a sufficient case for it; a sufficient case would require that the solution it provided be superior to any alternative. In service of this requisite, the received history of Federation will often briefly pause to dispose of the Federal Council of Australasia (FCA) as an alternative to Federation.

The case against the FCA is that it was 'ineffectual' and 'born lame' (Crisp, 1990, pp. 11, 65) and even faintly farcical. Thus Robert Garran clears the board of the FCA with the derisive remark: 'It passed a few acts about pearl-shell fishing and beche-de-mer fisheries' (Garran, 1958, p. 85).

This remark is the template for usual treatment of the FCA, and indeed for the total neglect.

20 Perhaps a strength of Federation is that it accommodated and gratified the existence of inconsistent attractions to both nation and Empire. 
Queensland Pearl Shell and Beche-de-mer Fisheries (Extra-territorial) Act 1888: This seemingly laughable piece of legislation from the FCA is in fact an exercise in labour standards, and includes such stipulations as that deaths be reported, that native labourers be 'carried on ship's articles', and that native labourers be paid in the presence of a shipping master.

Other FCA legislation included the Australasian Civil Processes Act 1886, the Federal Garrisons Act 1893, the Australasian Naturalization Act 1897 and the Australasian Testamentary Processes Act 1897, which provided that the orders of the courts of one colony regarding a will would have force in all colonies. ${ }^{21}$ The legislation is not contemptible, and served both justice and utility. They do certainly have less 'sweep' than that passed by the Commonwealth in the first 12 months of the inauguration of parliament. They lack the sweep of the Pacific Island Labourers Act 1901, which undertook to deport every Kanaka by 31 December 1906; or the strength of the Immigration Restriction Act 1901 (the White Australia Policy), which prohibited the entry into Australia of any one with a contract to perform manual labour, or the Commonwealth Franchise Act 1902, which deemed 'no aboriginal native of Australia ... shall be entitled to have his name placed on an Electoral Roll'. ${ }^{22}$

The evident potential for the Federal Council to pass useful legislation does open a question that Federation historiography, through its contempt, partly closed: why did not NSW join to FCA? Why did Dibbs decline McIlwraith's exhortation to join; or Reid declare he did not give a 'fig' for the Council? No work has been done on this question. The literature on the council is slender; perhaps only two papers over the past century. It appears no $\mathrm{PhD}$ thesis exists. ${ }^{23}$ And this scholarly neglect is perfectly in accord with the justificationist, if not celebratory, stance of Federationist historiography.

\section{Contingency, continuity and connections}

Apart from the deconstruction and debunking, what constructively would a revisionist account of Federation do?

A revisionist history commonly draws on different explanatory resources than original history.

21 A quarantine bill was in process when the Federal Council last met in 1899.

22 The Constitution, at least in theory, placed an inhibition on this prohibition.

23 Trove records no more than an MA thesis (Harris, 1971) and a BA thesis (Anstey, 1971). Crisp's (1990) wideranging bibliography of Federationist literature, which runs up to about 1980, records Harris, but nothing else. 


\section{Contingency}

An 'achievement' is more than a piece of good fortune, or luck. Many observers have felt the realisation of Federation of 1901 was a matter of chance. Thus at the close of 1894, with Barton out of parliament, Griffith sidelined on the bench, Parkes in isolation and NSW Government in the hands of Reid and John Want, the rational likelihood of Federation coming soon must have been low. But within five years the cause was invincible. This bespeaks favourable, but chance ('unusual'), events. This has been freely recognised, both in recent years and in the first phase. Thus Deakin would refer to a 'miracle' (Deakin, 1963, p. 173); the same thought in pejorative terms would have Federation as a 'freak'. But however the fact is expressed, the contingency puts to sword functionalist grounds (tariffs, railways) or deterministic forces (swellings, rising tides of national sentiment). Eyes would turn to the unusual, unpredictable fluctuations in circumstances, the strange, unaccountable decision.

\section{Continuity}

Federationist history is premised on Federation being an 'achievement'. A critic might see Federation as a misstep, a wrong turn, a blunder, a folly. But an entirely different dissent from affirmative Federation history would see Federation as a non-event. So 1901, rather than being a fork in the road, a rupture, a Year Zero, was, in this view, just more of the same old, same old.

The existence of 'federation before Federation' is well recognised; reflected in a style of governance of nineteenth-century Australia amounting to the imitation and cooperation of the six governments, rather than differentiation and competition. It is evinced in numerous intercolonial conferences, and the tendency to borrow legislation from one another. The Federation of 1901, it might seem, was no more than an intensification of this 'federation before Federation'. Thus the creation of an army of the Commonwealth could be taken as just a culmination of the 'federalisation' of the various armed forces that had proceeded during the 1890s. Federationist immigration might illustrate the continuity thesis still more strongly. The White Australia Policy had its concrete origins in the intercolonial conference resolution of 1888 to extend anti-Chinese Acts to all 'Asiatics'. This resolution was matched in the following decade by increasingly severe legislation culminating in the 'dictation test' legislation in NSW, WA and Tasmania of the late 1890s. The Immigration Restriction Act 1901 was, in this continuity interpretation, just a sharpening up and tidying up of a policy already essentially decided upon without Federation. There was, after 1901, a severity in the black letter law and rigour in enforcement that were not to be found before 1901; but, for all that, Federation just hastened Australia down the road it was travelling anyway. 
But the continuity thesis is a tall order. Even in the one matter that it well fitsimmigration - the severe and sweeping Immigration Restriction Act 1901 evidently reflected a new political game (Norris, 1975); a new politics that had been inaugurated with the creation of a new polity; a new polity that was restricted in scope, and in consequence, endowed with an uncluttered agenda in comparison with colonial legislatures (so crowded with particularist causes), and yet still burdened with an imperative to win elections. In consequence, the new polity yielded an intensification of 'national' legislation gratifying 'valency' issues. The recasting of defence after 1901 manifests this new kind of politics, and, correspondingly, the inadequacy of the continuity thesis; it is hard to see the 1890s conferencing of brigadier generals and that decade's harmonisation of weaponry heralding the revolution of defence in the 10 years following 1901. Thus voluntarism-an active principle of pre-1901 armed forces - seemed to reach new heights at the very verge of Federation, and hardly betokened the visions of compulsory mass armies that were so beguiling to all political parties just 10 years later.

Beyond legislation, Federation did seem to amount to a rupture in time for one important particular of the Australian landscape: the Labor Party. The nexus between its remarkable take-off in after 1901 and Federation seems not to have engaged, or even been acknowledged, by the historians of Labor. ${ }^{24}$ There lies a task undone.

\section{Connections}

Another salient resource of explanation revisionism is the networks of persons, in contrast to the reliance of unrevised history on impersonal forces (ideas and interests). That such a stress is diminishing (and so revisionist) is plain enough; events-important events-are the product of the machinations of self-serving cliques. The drama, even grandeur, of political 'waves', 'eruptions' and 'earthquakes' is removed.

Federation promises to be a rich field for the study of the power of personal networks. The nerve centre of the movement seems to coincide with a complex of barristers and judges: Barton, O’Connor, Reid, Wise, Griffith, Clark, Deakin, Isaacs, Kingston, Symons (and Glynn). The legal profession at which judges and barristers were the centre was an intense, still small, even intimate, brotherhood, nourished by common education, shared employment, professional bodies, friendships and, of course, briefs passing back and forth continually between them. At the centre of the Australian political fish tank of the 1890s was a highly intelligent, jet-propelling, carnivorous, multi-armed tentacular organism.

24 Thus Hagan and Turner (1991) ascribe the revival of the fortunes of NSW Labor 'around the turn of the century' to the NSW Conciliation and Arbitration Act 1901, the recovery of trade unions from the 1890s, the legitimation of the party in Catholic eyes, and the expansion of the wheat belt. Rickard appears to judge Federation of greater significance for the non-Labor side of politics (Rickard, 1976, p. 166). 


\section{The seamy side}

This is where official history rarely probes, but revisionist history achieves notoriety by doing so. This is the hidden, unattractive but necessary part of any showy garment. Being hidden, the seamy side of Federation is a challenge to record, but traces can be detected.

\section{The money plumbing}

This is the funding of Federationist campaigning in NSW and WA (and presumably Queensland) by donors from Victoria and SA. Deakin was certainly a director of these flows. ${ }^{25}$ It is possible that, as rumoured, King O'Malley was the palpable duct of some of them. And it is at least plausible that Deakin's son-in-law, Herbert Brookes, acted as a financial irrigator of the politically parched far reaches of Australia, as he did for Deakin's Commonwealth Liberal Party 10 years later.

These unsentimental activities have been given most attention by Hirst, who in one dense paragraph reproduces some allegations, and notes some of the extant, if disguised, records of it (2000, p. 260). Obviously, the covert nature of this activity reduces the evidence, but detective work may give a clearer and interesting picture.

\section{Electoral fraud}

The ultimate unmentionable in the Federation history is the blighting of the referendums by electoral fraud. Such fraud was a curse of nineteenth-century elections (Nairn, 1967; Walker, 1977), and concerted effort was made with the NSW Parliamentary Elections Act 1893 to stay it. But the equally strenuous efforts of Reid in 1899, and Forrest in 1900, to secure a 'Yes' vote produced a relaxation of safeguards. It is a matter of public record that fraud was executed in WA. And it would also seem likely, on the basis of the aberrant size of recorded votes, there was a mound of fraudulent 'Yes' votes in the Riverina electorates, and fraudulent 'No' votes in Sydney-Lang. ${ }^{26}$

\footnotetext{
25 Thus Deakin to Symon, 15 July 1898. 'Dear Mr. Symon: I have just had a verbal request from Sydney to write you to see if your League can in the strictest privacy spare any funds or raise them to assist the fight in the Broken Hill seats ...' (quoted in Wright, 1976; emphasis in original).

26 On the face of it, the 119.9 per cent turnout recorded in Sydney-Lang is a marvel of democratic achievement, which no ballot in our postlapsarian times can hope to touch. But it may be retorted that NSW voters in the 1899 referendum were permitted to cast the vote absentee, and one might impute the outsize turnout to absentee votes. And yet, why should Sydney-Lang exhibit such a mass of visiting electors? The fact that the electorate strongly voted 'No' reinforces the thought that Hughes' Labor machine—-strongly opposed to federation—was organising fraudulent ballots. See Hughes (1947).
} 
It would be worthwhile to see if 'seeming likelihood' of ballot fraud could be transformed into a more pronounced judgement, one way or another. There is a literature, chiefly concerned with nineteenth-century US referendums, that models turnout statistically, and so allows the testing (and potential rejection) of the hypothesis of turnouts of particular booths being normal, and 'thus' being inexplicable only by fraud (Baum, 1991; Baum \& Halley, 1994). With the advent of post-1989 democracies, a distinct literature has developed turning on the fact of psychology that the relative frequencies of certain digits of fake returns are not equal to 0.1 , as they will (approximately) equal in natural data. Like any statistical test, both approaches will sometimes yield false negatives, and sometimes false positives, but they are not valueless because of that.

\section{Counterfactuals}

Counterfactual history by revisionists is subject to the danger of being no more than wish fulfilment fantasy. But 'used with care', the speculation over counterfactuals is a legitimate part of the repertoire of revisionist history. With respect to the case of Federation, the use of counterfactuals is partly defensive: to rebut the silly counterfactuals sometimes indulged by received history; thus fancies of passport control and currency exchange at Tweed Heads in the absence of 1901. The mulling of counterfactuals might be additionally useful in exploring the contingency of Federation; and partly in exploring the hypothesis of continuity vs rupture. The formulation of convincing counterfactuals will bring to the table a historicist or social science perspective on Federation, as any counterfactual that is not gratuitous must draw on them. Finally, the cultivation of counterfactuals illustrates in partat least potentially - the possibility of a better twentieth century, not based on no Federation, but on a better one.

\section{The upshot}

A revisionist treatment of history opens up a path for a more constructive inquiry into Federation. If Federation was not 'an achievement', what was it?

\section{References}

Anstey, J. (1971). South Australia and the Federal Council 1883-1899 [BA (Hons) thesis]. University of Adelaide.

Baum, D. (1991). Pinpointing apparent fraud in the 1861 Texas secession referendum. Journal of Interdisciplinary History, 22(2), 201-221. doi.org/10.2307/205866. 
Baum, D. \& Hailey, J.L. (1994). Lyndon Johnson's victory in the 1948 senate race: A reappraisal. Political Science Quarterly, 109(4), 595-613. doi.org/10.2307/2151840.

Bolton, G. (2000). Edmund Barton. Allen \& Unwin.

Botsman, P. (2000). The great constitutional swindle: A citizen's view of the Australian Constitution. Pluto Press.

Broinowski, R. (1949). The first five prime ministers of Australia. Journal of the Royal Australian Historical Society, 35(2), 81-116.

Bryce, J. (1905). Constitutions. Oxford University Press.

Clifford, E., Green, A. \& Clune, D. (Eds). (2006). The electoral atlas of New South Wales 1856-2006. Department of Lands.

Crisp, L.F. (1949). The parliamentary government of the Commonwealth of Australia. Longmans, Green.

Crisp, L.F. (1990). Federation fathers (J. Hart, Ed.). Melbourne University Press.

Davison, G., Hirst, J. \& Macintyre, S. (Eds). (2001). The Oxford companion to Australian history. Oxford University Press. doi.org/10.1093/acref/9780195515039.001.0001.

Deakin, A. (1944). The Federal story: The inner history of the Federal cause. Robertson \& Mullens.

Deakin, A. (1963). The Federal story: The inner history of the Federal cause, 1880-1900 (J.A. La Nauze, Ed.). Melbourne University Press.

Deakin, A. (1968). Federated Australia: Selections from letters to the Morning Post 1900-1910 (J.A. La Nauze, Ed.). Melbourne University Press.

Evatt, H.V. (1945). Australian labour leader: The story of W.A. Holman and the labour movement (3rd ed.). Angus and Robertson.

Fitzgerald, R. (2002). The federation mirror: Queensland 1901-2001, with the assistance of Keith Moore. University of Queensland Press.

Garran, R.R. (1936). Australia. In, J. Holland Rose, A.P. Newton \& E.A. Benians (Eds), The Cambridge history of the British Empire (Volume 7, Part 1). Cambridge University Press.

Garran, R.R. (1958). Prosper the Commonwealth. Angus and Robertson.

Grimshaw, P. (2002). Federation as a turning point in Australian history. Australian Historical Studies, 33(118), 25-41. doi.org/10.1080/10314610208596177.

Hagan, J. \& Turner, K. (1991). A history of the Labor Party in New South Wales, 1891-1991. Longman Cheshire.

Hall, H.L. (1931). Victoria's part in the Australian Federation movement, 1849-1900. Elliot Stock. 
Harris, I.C. (1969). The Federal Council of Australasia [MA thesis]. University of Newcastle.

Hirst, J. (2000). The sentimental nation: The making of the Australian Commonwealth. Oxford University Press.

Hughes, W.M. (1947). Crusts and crusades: Tales of bygone days. Angus and Robertson.

Hyam, R. \& Martin, G. (1975). Reappraisals in British imperial history. Macmillan.

Lloyd, P. (2015). Customs union and fiscal union in Australia at Federation. Economic Record, 91(293), 155-171.

Martin, G. (2001). Australia, New Zealand and Federation, 1883-1901. Menzies Centre for Australian Studies.

Martin, G. (2003). Explaining the sentimental Utopia: Historians and the Centenary of Australian Federation. Australian Studies, 19(1), 211-230.

McMinn, W.G. (1989). George Reid. Melbourne University Press.

Meaney, N. (2001). Britishness and Australian identity: The problem of nationalism in Australian history and historiography. Australian Historical Studies, 32(116), 76-90. doi.org/10.1080/10314610108596148.

Moore W. H. (1902). The Constitution of the Commonwealth of Australia. John Murray.

Nairn, B. (1967). The political mastery of Sir Henry Parkes: New South Wales politics 1871-1891. Journal of the Royal Australian Historical Society, 53(1), 1-51.

Nairn, B. (1973). Civilising capitalism: The Labor Movement in NSW 1879-1900. Australian National University Press.

Nethercote, J.R. (2002). Liberalism, the Federation and Australian prime ministers. Canberra Historical Journal, 50(September), 13-25.

New South Wales Parliamentary Debates. (1890, 5 June). Legislative Council. Speaker: Andrew Garran.

Norris, R. (1975). The emergent Commonwealth: Australian Federation, expectations and fulfilment 1889-1910. Melbourne University Press.

Parker, R.S. (1949). Australian federation: The influence of economic interests and political pressures. Historical Studies: Australia and New Zealand, 4(13), 1-24.

Pulsford, E. (1917). Commerce and the Empire: 1914 and after. P.S. King \& Son.

Quick, J. \& Garran, R.R. (1901). The annotated constitution of the Australian Commonwealth. Angus \& Robertson.

Reynolds, J. (1948). Edmund Barton. Angus and Robertson.

Rickard, J. (1976). Class and politics. Australian National University Press. 
Souter, G. (1976). Lion and kangaroo. Book Club Associates.

Tennyson, A. (1978). Audrey Tennyson's vice-regal days: The Australian letters of Audrey, Lady Tennyson to her mother Zacyntha Boyle, 1899-1903 (A. Hasluck, Ed.). National Library of Australia.

Tyrell, J.R. (1987). Old books, old friends, old Sydney. Angus and Robertson.

Viner, J. (2013) [1950]. The customs union issue (P. Oslington, Ed.). Oxford University Press.

Walker, R.B. (1977). Some aspects of electoral reform in new South Wales 1858-1893. Journal of the Royal Australian Historical Society, 63, 149-166.

Wise, B.R. (1913). The making of the Australian Commonwealth, 1889-1900: A stage in the growth of the Empire. Longmans Green.

Wright, D.I. (1976). The dawn of Federation: Some episodes, letters and personalities and a vindication. South Australiana, 15(2), 113-151. 
This text is taken from Agenda, Volume 27 - Number 1, 2020, edited by William Coleman, published 2020 by ANU Press, The Australian National University, Canberra, Australia.

doi.org/10.22459/AG.27.01.2020.04 